\title{
SOME CRUCIAL AREAS IN SCIENCE EDUCATION RESEARCH CORRESPONDING TO THE NEEDS OF THE CONTEMPORARY SOCIETY
}

\author{
Miia Rannikmäe \\ University of Tartu, Estonia
}

Innovative societies need people who are equipped with scientific and technological competences e.g. are scientifically literate. Being scientifically literate encompasses a large set of competences, many beyond those which are directly linked with exhibiting acquired scientific knowledge. While PISA studies mainly give a comparison of students' science knowledge, thinking and process skills, the assessment is not so much about the skills needed in the workplace or functioning in society as a responsible citizen. This suggests there is a need for further comparative studies to cover this deficit. Such kind of research is essential directed to those countries which have shown high results in PISA studies (e.g. Estonia) in order to interpret PISA results more widely in new contexts. This is especially highlighted by recent findings from research carried out among a representative sample of Estonian gymnasium students. The outcomes showed that students' problem solving, decision-making and reasoning skill do not significantly change during the gymnasium years, even though the amount of science factual knowledge is increasing (Rannikmäe, Reiska \& Soobard, 2014, Soobard \& Rannikmäe, 2014).

Society also needs more scientists in order to respond to challenges in science, medicine, economy, political and social debates, etc. (EC, 2004). Internationally, a well - known problem over the years has been that science education has tended to be perceived as irrelevant in eyes of students, especially when, as is usually the case, it is more focused on promoting subject-related content than promoting skills needed for life and careers, such as investigatory skills linked to inquiry-based science education (EC,2007). This is a recognized area of concern in science education worldwide. Emphasis on subject content related teaching has caused gaps between students'/ society needs and school science teaching and finally a drop in student interest in science learning, which is linked with decreasing number of students choosing science-related careers and studies at tertiary level (EC 2007; 2009; 2010). This suggests there is a strong need to place more emphasis on interdisciplinary cross-curricula skills, sometimes suggested as $21^{\text {st }}$ century skills $(P S, 2009)$ and lately given particular attention in the American next generation science standards (NRC, 2012). Perhaps this can aptly be summarised as seeing the importance of promoting 'education through science' rather than an approach giving the major attention to science, as in a science through education approach (Holbrook \& Rannikmae, 2007)

But the educational emphasis is not only felt in the learning context. Implementing and acknowledging the need for new pedagogies in science education has become extremely important. New approaches are needed to create opportunities for students to be actively involved in learning in a motivational way not only in the classroom, but also outside of traditional school lessons. Paying more attention to motivation teaching in which the science education learning is more context-focused and the context is taken to be the society, or the concerns and issues within the society. In the context of science popularisation, this means that it is not enough to introduce to students, new, updated developments in science, but students need to see its relevance in a societal sense and to have the opportunity to be actively involved in thinking and discussing, as well as having such processes extended after any initial interaction is finished.

Making science education and science-related careers attractive for young people is an ambitious goal, since it targets no less a goal than to drastically improve the scientific and technological literacy in our society by giving value and enjoyment to science education learning. Such literacy needs to strive to achieve innovative awareness 
of the different dimensions encompassing science and technology in today's society (and in a society sense it is almost impossible to separate science from engineering and technology) and to address the challenges faced by young people when pursuing STEM careers.

Generally student awareness about science-related careers is low. Students don't see the link between knowledge and acquiring competences, which is essential for career choices during their gymnasium studies. This gap tends to set science aside from the educational learning thrusts of other subject areas. While school science education is predominantly targeting the need to acquire science content knowledge, it is all too often far from being updated to a contemporary science level. On the other hand, popularization of science content and related activities overcome the gap issue at a contemporary science level, but are lacking behind in the education area where promotion of competences is an essential part of the curriculum. Competence development, especially interrelating skills and values helps to ensure students' readiness for an independent life and concurrence at the workplace. These competences, commonly agreed worldwide, are linked to critical thinking, problem solving, decision making, communication both collaboratively and through value considerations (PS, 2009).

Research carried out among stakeholders including industrialists and employees confirm a high demand for workers having wider skills, positive attitudes and social values (Post \& Rannikmae, 2011). Further, research has shown also that a student's career awareness needs to be promoted throughout schooling, with the latest starting time being the beginning of lower secondary studies (Maltese \&Tai, 2011). NRC (2012) in reflecting on the Next Generation Science Standards, recommends the promotion of science-related career awareness and competences in the context of so called "big ideas" in science throughout schooling in order to form a solid and conceptual framework among learners.

In the context of promoting science-related careers, it is not enough for students to carry out a few investigations, even if based on innovative science related experiments, which they may not be able to do at school because of the absence of experimental equipment, or science expertise. Students need, for example, to experience learning in society-related decision-making, which is linked with authentic problem solving investigations or inquiries. This can become the case when new pedagogies are implemented and school-popularization teams develop programmes, which support long lasting learning and enhance relevance and motivation. Research has repeatedly shown that 'new' is interesting to students, but getting students to show interest led by situational extrinsic motivation is not enough to sustain such interest. Unfortunately such interest promotion within students does not lead to the formulation of personally promoted, intrinsic motivation, this forming the basis for enhanced meaningful learning and setting the stage for greater career awareness and attraction to science - related careers.

Over several years, different organizations, including universities, have been funding activities for the popularization of science among young people. Special attention has been on those, which, besides increasing students' interest towards science, also support the school curriculum. Among such kind of activities are mobile operations, for example "Moving laboratories" and "BioBus" in Estonia and Lithuania. And usually, after visits to schools, feedback collected from students is very positive, as tends to be the case whenever students experience something new. However, the effectiveness of such activities is not studied from a wider prospective such as the influence of a single visit on increasing students' motivation and interest towards further long-lasting science learning. The impact of such popularising activities on career choices in STEM areas needs further investigation.

Studies are also needed to find out how schools, teachers and science popularization teams are communicating and how the goals and expected outcomes of the activities are linked with the wider goals associated with the school curriculum goals, such as promoting problem solving and decision-making skills, supporting creativity and reasoning - all important and necessary attributes for science related careers. Such issues, identified above are important internationally and provide the need to work out a theoretically justified framework and instrumentation for the evaluation of the effectiveness of science popularization, mobile activities, which support meetings/ promotion of curriculum goals.

This, research can be suggested as needed to find out on what kind of influences can be determined for the impact of science popularization mobile activities on students' career choices e.g. starting science related studies at the tertiary level. This can be expected to include the manner and impact of such activities/meetings/attitudes/ role models of science popularization staff on the challenges in choosing and start studies at the tertiary level. In such research the target group is changed, replacing school students with the learners at the tertiary level. Research questions can be considered such as - what are (and how can we identify) first year undergraduates' attitudes towards science-related career options and are these domain specific? (e.g. which competences are preferred/essential during career choice, have science popularization mobile activities changed the students' at- 
titudes towards science-related careers, do science teachers influence career choice and if so what science teacher factors are important, are there any alternative personal choices, etc.?). And finally, what kind of relationship can be determined, in the eyes of first year undergraduate students, between the goals and expected learning outcomes of science learning, science popularization mobile activities and the promotion of essential competences for science-related careers?

\section{References}

Holbrook, J, \& Rannikmae, M. (2007). Nature of science education for enhancing scientific literacy. International Journal of Science Education, 29 (11), 1347-1362.

European Commission (EC). (2007). Science education now: A renewed pedagogy for the future of Europe. Brussels: EC.

European Commission (EC). (2009). Challenging futures of science in society. Emerging trends and cutting-edge issues. The Masis Report. Brussels: EC.

European Commission (EC). (2010). Employers' perception of graduate employability. Analytical Report. Brussels: EC.

Maltese, A.V., \& Tai, R. H. (2011). Pipeline persistence: Examining the association of educational experiences with earned degrees in STEM among U.S. students. Science Education, 95, 877-907.

NRC. (2012). Framework for K-12 science education: Practices, crosscutting concepts and core ideas. National Academies Press. Retrieved from http://www.nap.edu.

Partnership for $21^{\text {st }}$ Century Skills (PS). (2009). P21's Framework for 21st Century Learning. Retrieved from http://www.p21.org pur-work/p21-framework

Post, A., Rannikmäe, M., \& Holbrook, J. (2011). Stakeholders views on attributes of scientific literacy important for future citizens and employees - A Delphi study. Science Education International, 22 (3), 202-217.

Rannikmäe, M., Reiska, P., \& Soobard, R. (2014). Loodusteaduslik kirjaoskus gümnaasiumiõpilaste karjäärivaliku mõjutajana (LoTeGüm). Unpublished research report. Tartu, Estonia.

Soobard, R., \& Rannikmäe, M. (2014). Upper secondary students` self-perceptions of both their competence in problem solving, decision making and resoning within science subjects and their future careers. Journal of Baltic Science Education, 13 (4), 544-558.

Received: February 25, 2016

Accepted: February 28, 2016

Miia Rannikmäe

PhD., Professor, Head of the Center for Science Education, Faculty of Science and Technology, University of Tartu, Ülikooli 18, 50090 Tartu, Estonia. E-mail:miia.rannikmae@ut.ee 